\title{
The Boarding House
}

Excuse me

but could you lower your voice?

You speak so loud

and endlessly

You delete my choice.

Excuse me

but what are you trying to say?

who you trying to convince

and convert

to your ways?

I've got so many voices in my head

they should be paying rent

I've got tenants quoting

Jesus, Neruda, Mercedes Sosa

T.S. Eliot, Benedetti, Huxley, Berg, and J.F.K.

Marx, Trudeau, Allende, Gandhi,

Weber, Durkheim, and Nietzche

have the balcony suites

they order room service

and debate

proletarianization of the masses

abortion, $\mathrm{CO} 2$ emissions, taxation and representation.

Don't even get them started

on sex, drugs, healthcare, and education.

They have agreed on many an item:

Build a missile

educate a child

subsidize a zoo

clear cut a rainforest

free testing for HIV

and treat them like lepers. 
So you see...

If you want to speak

you'll have to wait your turn.

So far the vote of confidence

in the legislature of my mind

for each border

has come up nay.

Take a number

have a seat

I've got a lot of living and histories to digest

before I get to you

so don't fall in love

with the sound of your own voice

you'll always find

it's only a filtration system for your own

Cerebral Hotel

but at least

we've got

the power of choice.

Tania Guerrero 